\title{
Pott disease causing chin-on-chest deformity and myelopathy
}

Figure Severe kyphosis and spinal cord compression due to Pott disease

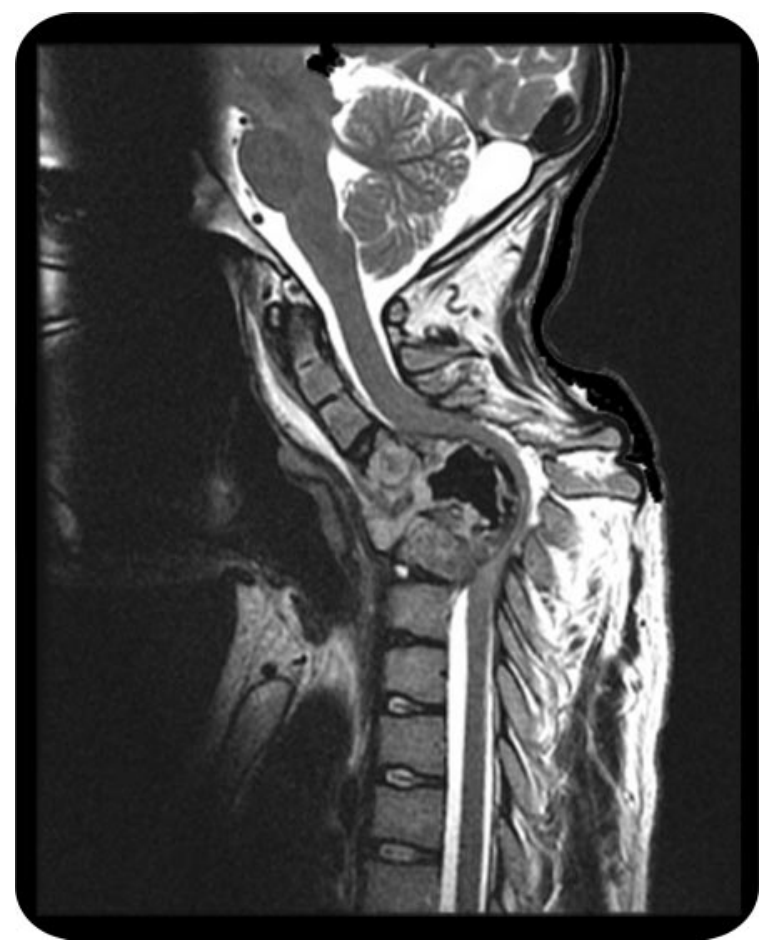

Preoperative MRI shows extensive destruction of 7 vertebral segments (C4-T3), with concomitant kyphosis and spinal cord compression.

A 20-year-old man had a 2-month history of progressive gait abnormality, leg discomfort, and "coldness." He had immigrated 5 years earlier and worked at a meat-packing plant. There was a chin-on-chest deformity. MRI of the cervical spine showed a destructive process affecting multiple vertebral segments (figure). Differential diagnosis included malignancy or infection. PPD and QuantiFERON Gold test for tuberculosis were positive. Treatment involved isoniazid, rifampin, pyrazinamide, ethambutol, and pyridoxine. ${ }^{1}$ Although Pott disease can be effectively treated medically, neurologic deficit or severe deformity are indications for surgery. ${ }^{2}$ The patient underwent anterior debridement and C4-T3 vertebrectomies, with interbody cage reconstruction followed by posterior segmental fixation. Intraoperative specimen was AFB positive; culture yielded Mycobacterium tuberculosis. At follow-up, the patient was able to ambulate upright and independently.

\section{Paul Park, MD, Cheerag Upadhyaya, MD, Ann Arbor, MI}

Disclosure: Dr. Park serves on the editorial advisory board for The Open Spine Journal; receives royalties from the publication of Spinal Reconstruction: Clinical Examples of Applied Basic Science, Biomechanics, and Engineering (Informa Healthcare USA, 2007); serves as a consultant for Depuy AcroMed and Medtronic Spine; estimates that $95 \%$ of his clinical effort is spent performing spinal surgery; and receives research support from Blackstone Medical and the NIH (HD059259-04A2 [Co-I]). Dr. Upadhyaya reports no disclosures. Address correspondence and reprint requests to Dr. Paul Park, Department of Neurosurgery, University of Michigan Health System, 1500 E. Medical Center Drive, Room 3552 Taubman Center, Ann Arbor, MI 48109-5338; ppark@umich.edu

1. Bass JB Jr, Farer LS, Hopewell PC, et al. Treatment of tuberculosis and tuberculosis infection in adults and children: American Thoracic Society and The Centers for Disease Control and Prevention. Am J Respir Crit Care Med 1994;149:1359-1374.

2. Moon MS. Tuberculosis of the spine: controversies and a new challenge. Spine 1997;22:1791-1797. 


\section{Neurology}

\section{Pott disease causing chin-on-chest deformity and myelopathy \\ Paul Park and Cheerag Upadhyaya \\ Neurology 2010;75;477 \\ DOI 10.1212/WNL.0b013e3181eb58a2}

This information is current as of August 2, 2010

Updated Information \&

Services

References

Subspecialty Collections

Permissions \& Licensing

Reprints including high resolution figures, can be found at:

http://n.neurology.org/content/75/5/477.full

This article cites 2 articles, 0 of which you can access for free at: http://n.neurology.org/content/75/5/477.full\#ref-list-1

This article, along with others on similar topics, appears in the following collection(s):

All Clinical Neurology

http://n.neurology.org/cgi/collection/all_clinical_neurology

All Infections

http://n.neurology.org/cgi/collection/all_infections

All Spinal Cord

http://n.neurology.org/cgi/collection/all_spinal_cord

MRI

http://n.neurology.org/cgi/collection/mri

Information about reproducing this article in parts (figures,tables) or in its entirety can be found online at:

http://www.neurology.org/about/about_the_journal\#permissions

Information about ordering reprints can be found online:

http://n.neurology.org/subscribers/advertise

Neurology ${ }^{\circledR}$ is the official journal of the American Academy of Neurology. Published continuously since 1951, it is now a weekly with 48 issues per year. Copyright. All rights reserved. Print ISSN: 0028-3878. Online ISSN: 1526-632X.

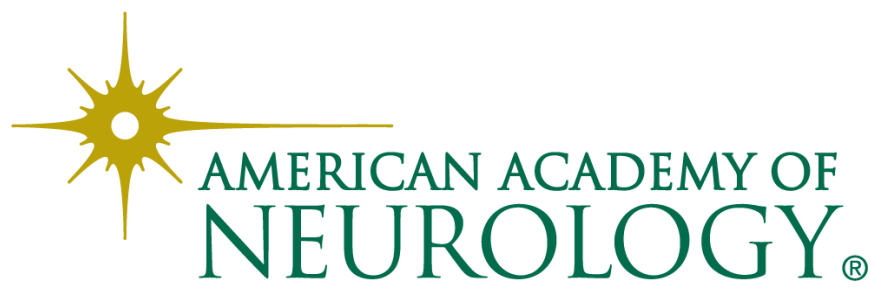

